\title{
PENGARUH LINGKUNGAN KELUARGA DAN LINGKUNGAN SEKOLAH TERHADAP KESULITAN BELAJAR SISWA SMA NEGERI 2 SINGARAJA TAHUN PELAJARAN 2016/2017
}

\author{
Luh Eva Aristha \\ Jurusan Pendidikan Ekonomi \\ Universitas Pendidikan Ganesha \\ Singaraja, Indonesia \\ e-mail: evaid467@gmail.com
}

\begin{abstract}
Abstrak
Penelitian ini bertujuan untuk mengetahui pengaruh lingkungan keluarga terhadap kesulitan belajar pada siswa SMA Negeri 2 Singaraja, pengaruh lingkungan sekolah terhadap kesulitan belajar pada siswa SMA Negeri 2 Singaraja, dan pengaruh lingkungan keluarga dan lingkungan sekolah secara simultan terhadap kesulitan belajar pada siswa SMA Negeri 2 Singaraja. Jenis penelitian ini merupakan penelitian deskriptif kuantitatif. Data dikumpulkan dengan metode kuesioner. Teknik analisis data menggunakan analisis regresi linier berganda berbantuan program SPSS 24.0 for Windows. Hasil penelitian menunjukkan bahwa secara parsial lingkungan keluarga berpengaruh signifikan terhadap kesulitan belajar, yang ditunjukkan dengan nilai $t_{\text {hitung }}=3,951>t_{\text {tabel }}=2,024$ dan nilai probabilitas uji t 0,000 yang lebih kecil dari $\alpha=0,05$; secara parsial lingkungan sekolah berpengaruh signifikan terhadap kesulitan belajar, yang ditunjukkan dengan nilai $t_{\text {hitung }}=3,146>t_{\text {tabel }}=$ 2,024 dan nilai probabilitas uji t 0,003 yang lebih kecil dari $\alpha=0,05$; secara simultan lingkungan keluarga dan lingkungan sekolah berpengaruh signifikan terhadap kesulitan belajar, yang ditunjukkan dengan nilai $F_{\text {hitung }}=16,766>F_{\text {tabel }}=3,260$ dan nilai probabilitas uji $F$ 0,000 yang lebih kecil dari $\alpha=$ 0,05 .
\end{abstract}

Kata kunci: lingkungan keluarga, lingkungan sekolah, kesulitan belajar.

\begin{abstract}
This research was aimed to identify the effect of family environment on learning difficulties in SMA Negeri 2 Singaraja students, the effect of school environment on learning difficulties in SMA Negeri 2 Singaraja students, and the effect of family environment and school environment simultaneously to learning difficulties in SMA Negeri 2 Singaraja students. This research was quantitative descriptive research. The data collected by questionnaires. Data analysis technique using multiple linear regression analysis assisted program SPSS 24.0 for Windows. The results showed that partially family environment had a significant effect on the learning difficulties, as indicated by value of $t_{\text {test }}=3.951>$ $t_{t a b l e}=2.024$ and probability value of $t$ test $0.000<\alpha=0.05$; partially school environment had a significant effect on the learning difficulties, as indicated by value of $t_{\text {test }}=3.146>t_{\text {table }}=2.024$ and probability value of $t$ test $0.003<\alpha=0.05$; simultaneously family environment and school environment had a significant effect on the learning difficulties, as indicated by value of $F_{\text {test }}=16.766>F_{\text {table }}=$ 3.260 and probability value of $F$ test $0.000<\alpha=0.05$.
\end{abstract}

Keywords: family environment, school environment, learning difficulties. 


\section{PENDAHULUAN}

Proses belajar mengajar merupakan hal yang menjadi kegiatan pokok di setiap sekolah. Menurut Yamin (2007:59), "Proses belajar mengajar merupakan proses yang sistematik, artinya proses yang dilakukan oleh guru dan siswa di tempat belajar dengan melibatkan komponen-komponen yang saling berinteraksi untuk mencapai suatu tujuan belajar". Jika dilihat dari sisi output atau hasil yang ingin dicapai, proses belajar mengajar yang dilakukan dimanapun tentu bertujuan untuk mencetak Sumber Daya Manusia (SDM) yang berkualitas. Dalam mencapai tujuan proses belajar mengajar perlu adanya komponen pendukung agar tercipta proses belajar mengajar yang berkualitas.

Menurut Djamarah (2006), komponen-komponen proses belajar mengajar yaitu, (1) siswa adalah seorang yang bertindak sebagai pencari, penerima, dan penyimpan isi pelajaran yang di butuhkan untuk mencapai tujuan; (2) guru adalah seseorang yang bertindak sebagai pengelola, dan peran lainya yang memungkinkan berlangsungnya kegiatan belajar mengajar yang efektif; (3) tujuan merupakan pernyataan tentang perubahan prilaku; (4) isi pelajaran adalah segala informasi berupa fakta dan konsep yang di perlukan untuk mencapai tujuan; (5) metode adalah cara yang teratur untuk memberikan kesempatan kepada siswa untuk mendapat informasi yang di butuhkan untuk mencapai tujuan; (6) media adalah bahan pengajaran dengan atau tanpa peralatan yang digunakan untuk menyajikan informasi kepada siswa; (7) evaluasi adalah cara tertentu yang di gunakan untuk menilai suatu proses dan hasilnya. Proses belajar mengajar akan berkualitas jika setiap komponen proses belajar mengajar tersebut mampu berinteraksi dan membentuk sistem yang saling berhubungan sehingga tercapai tujuan dari proses belajar mengajar tersebut. Namun, tidak semua proses belajar mengajar di sekolah dapat mencapai tujuan yang telah ditetapkan. Hal tersebut terjadi karena adanya kendalakendala selama proses belajar mengajar berlangsung. Salah satu kendala yang sering dijumpai adalah kesulitan belajar yang dialami siswa.

Kesulitan belajar seorang siswa akan tampak pada penurunan prestasi akademik siswa. Menurut Dalyono (2009:229), "kesulitan belajar merupakan suatu kondisi siswa tidak dapat belajar sebagaimana mestinya". Menurut Djamarah (2011), Ciri-ciri siswa mengalami masalah kesulitan belajar dapat dilihat dari, (1) hasil belajar yang rendah (nilai di bawah rata-rata di dalam kelompok kelas); (2) hasil yang di capai tidak seimbang dengan usaha yang di lakukan; (3) lambat dalam melakukan tugas-tugas kegiatan belajar; (4) menunjukkan sikap-sikap yang berkelainan, seperti acuh tak acuh, menentang; (5) menunjukkan tingkah laku yang berkelainan, seperti membolos, datang terlambat, mengganggu di dalam atau di luar kelas, tidak mau mencatat pelajaran; (6) menunjukkan gejala emosi yang berkelainan, seperti pemurung, mudah tersinggung, pemarah, tidak atau kurang gembira dalam menghadapi situasi tertentu.

Setiap siswa pada prinsipnya mempunyai hak untuk memperoleh prestasi akademik yang memuaskan, namun dari kenyataan sehari-hari tampak bahwa siswa di dalam proses belajar tahunan sering mengalami kesulitan belajar sehingga prestasi belajarnya tidak optimal.

Kesulitan belajar dipengaruhi oleh beberapa faktor. Menurut Aqib (2002) faktor yang mempengaruhi kesulitan belajar bersumber dari faktor internal dan faktor eksternal. Faktor internal yang terdiri dari faktor biologis dan faktor psikologis sementara faktor eksternal terdiri dari faktor lingkungan keluarga, faktor lingkungan sekolah, dan lingkungan masyarakat. Fokus penelitian ini pada kesulitan belajar siswa yang berasal dari faktor eksternal yaitu lingkungan keluarga dan lingkungan sekolah. 
Peserta didik memiliki kepribadian yang berbeda-beda, sehingga dalam proses pembelajaran siswa memberi respon yang berbeda. Ada siswa yang mudah dalam menerima pelajaran dan ada siswa yang lambat dalam menerima pelajaran. Hal tersebut dipengaruhi oleh berbagai faktor. Salah satu faktor tersebut adalah lingkungan keluarga.

Keluarga merupakan lingkungan pertama yang membentuk karakter dan sikap seorang anak. Menurut Slameto (2010:60) "lingkungan keluarga merupakan pengaruh pertama dan utama bagi kehidupan, pertumbuhan, dan perkembangan seseorang". Lingkungan keluarga merupakan lembaga pendidik tertua, bersifat informal, yang pertama dan utama dialami oleh anak serta lembaga pendidikan yang bersifat kodrati orang tua bertanggung jawab memelihara, merawat, melindungi dan mendidik anak agar tumbuh dan berkembang dengan baik (Hasbullah, 2009). Menurut Gunarsa (2009:5), "lingkungan keluarga merupakan lingkungan pertama yang mula-mula memberikan pengaruh yang mendalam bagi anak". Sedangkan, Menurut Barnadib (2005:120), "lingkungan keluarga yaitu lingkungan yang bertanggung jawab atas kelakuan, pembentukkan kepribadian, kasih sayang, perhatian, bimbingan, kesehatan dan suasana rumah". Keluarga merupakan lingkungan sosialisasi pertama bagi seorang anak. Banyak waktu dan kesempatan bagi anak untuk berjumpa dan berinteraksi dengan anggota keluarga. Pola asuh keluarga akan sangat berpengaruh terhadap pembentukan karakter dan sikap anak.

Sebagaimana halnya dengan keluarga dan institusi sosial lainnya, sekolah merupakan salah satu institusi sosial yang mempengarui proses sosialisasi dan berfungsi mewariskan kebudayaan masyarakat kepada anak. Menurut Suwarno (2006), Lingkungan sekolah adalah lembaga pendidikan yang secara resmi menyelenggarakan kegiatan pembelajaran secara sistematis, berencana, sengaja, dan terarah, yang dilakukan oleh pendidik yang professional, dengan program yang dituangkan kedalam kurikulum tertentu dan diikuti oleh peserta didik pada jenjang tertentu, mulai dari Tingkat Kanak-kanak (TK) sampai Pendidikan Tinggi (PT). Menurut Ahmadi (2008:108), "sekolah merupakan salah satu institusi sosial yang mempengaruhi proses sosialisasi dan berfungsi mewariskan kebudayaan masyarakat kepada anak". Lingkungan sekolah dapat membentuk kepribadian siswa melalui pembelajaran dan peraturan-peraturan yang ada disekolah. Lingkungan sekolah juga memberikan pengajaran yang belum didapatkan dari lingkungan keluarga.

Berdasarkan hasil observasi awal di SMA Negeri 2 Singaraja, beberapa siswa mengalami masalah belajar. Dari guru Bimbingan Konseling (BK) diperoleh informasi bahwa masalah belajar pada umumnya disebabkan oleh lingkungan keluarga dan lingkungan sekolah. Siswa mengalami tekanan dari keluarga. Keluarga menaruh harapan terlalu tinggi pada siswa, bahwa siswa harus berprestasi sedangkan siswa tidak mampu untuk berprestasi. Harapan orang tua yang terlalu tinggi mengakibatkan siswa merasa tertekan saat belajar sehingga sulit untuk konsentrasi dalam menerima pelajaran. selain tekanan dari lingkungan keluarga, pergaulan siswa di sekolah juga sangat berpengaruh terhadap keberhasilan belajar siswa. Siswa yang bermasalah bergaul dengan siswa yang bermasalah lainya sehingga siswa tersebut mengalami masalah dalam belajar. Walaupun sekolah sudah menetapkan peraturan berupa disiplin, namun pelaksanaan aturan tersebut belum berjalan dengan baik. Hal ini dapat dilihat siswa tersebut datang terlambat pada saat jam pelajaran sudah dimulai sehingga mengalami banyak hambatan dalam belajar.

Tercatat empat puluh dua (40) orang siswa mengalami kesulitan belajar. Empat puluh orang siswa tersebut merupakan siswa yang bermasalah di sekolah. Untuk memperjelas permasalahan yang di alami siswa tersebut peneliti mewawancarai guru dan 
dapat diidentifikasi beberapa masalah kesulitan belajar siswa yaitu, (1) kurang memiliki perhatian di dalam belajar; (2) mudah lupa dengan materi yang telah di pelajari; (3) kesulitan dalam memahami materi yang di sampaikan guru;(4) rendahnya belajar siswa; (5) siswa lambat dalam melaksanakan dan mengumpul tugas yang di berikan oleh guru; dan (6) hasil belajar rendah.

Berdasarkan permasalahan yang terjadi di lapangan, penulis tertarik untuk melakukan penelitian yang bertujuan untuk mengetahui: (1) pengaruh lingkungan keluarga terhadap kesulitan belajar pada siswa SMA Negeri 2 Singaraja; (2) pengaruh lingkungan sekolah terhadap kesulitan belajar pada siswa SMA Negeri 2 Singaraja; dan (3) pengaruh lingkungan keluarga dan lingkungan sekolah secara simultan terhadap kesulitan belajar pada siswa SMA Negeri 2 Singaraja.

\section{METODE}

Penelitian ini merupakan jenis penelitian kausal. Menurut Sugiyono (2011), Penelitian kausal adalah penelitian yang menunjukkan hubungan variabel bebas dengan variabel terikat . Terdapat tiga variabel yang digunakan dalam penelitian ini yaitu dua variabel bebas dan satu variabel terikat. Variabel bebas dalam penelitian ini adalah adalah lingkungan keluarga $\left(X_{1}\right)$ dan lingkungan sekolah $\left(X_{2}\right)$, sedangkan variabel terikat dalam penelitian ini adalah kesulitan belajar (Y).

Subjek penelitian ini adalah siswa SMA Negeri 2 Singaraja yang pernah melakukan kesalahan sampai mendapat konseling khusus di ruang BK yang bejumlah 40 orang, sedangkan yang menjadi objek dalam penelitian ini adalah lingkungan keluarga, lingkungan sekolah, dan kesulitan belajar. Jenis data penelitian ini adalah data kuantitatif, yaitu data berupa angka-angka yang diperoleh dari jawaban responden mengenai kuesioner lingkungan keluarga, lingkungan sekolah, dan kesulitan belaiar. Data primer pada penelitian ini adalah data yang diperoleh langsung dari subjek yang diteliti. Data primer penelitian ini berupa kuesioner lingkungan keluarga, lingkungan sekolah, dan kesulitan belajar.

Adapun metode pengumpulan data yang digunakan dalam penelitian ini adalah metode kuesioner. Menurut Sugiyono (2013) Metode kuesioner digunakan untuk mendapatkan data tentang lingkungan keluarga, lingkungan sekolah, dan kesulitan belajar. Data yang telah dikumpulkan digunakan sistem skor, dimana jawaban pertanyaan diberi skor dengan menggunakan skala likert. Skala likert merupakan skala yang digunakan untuk mengukur, sikap, pendapat, dan persepsi seseorang atau sekelompok orang tentang fenomena sosial. Setiap pernyataan disediakan 5 (lima) alternatif jawaban, yaitu (1) apabila jawaban Sangat Setuju (SS) diberi skor 5; (2) apabila jawaban Setuju (S) diberi skor 4; (3) apabila jawaban Cukup Setuju (CS) diberi skor 3; (4) apabila jawaban Tidak Setuju (TS) diberi skor 2; dan (5) apabila jawaban Sangat Tidak Setuju (STS) diberi skor 1.

Kuesioner sebagai instrumen pengumpulan data sebelum digunakan untuk mengumpulkan data di lapangan terlebih dahulu harus diuji tingkat validitas dan reliabilitasnya. Untuk menguji tingkat validitas dan reliabilitas instrumen penelitian akan diujikan kepada 30 responden. Validitas adalah untuk melihat kecermatan alat ukur, yaitu mengukur apa yang akan diukur. Dalam penelitian ini, suatu kuesioner dinyatakan valid, jika pertanyaan maupun pernyataan pada kuesioner mampu untuk mengungkapkan sesuatu yang akan diukur oleh kuesioner tersebut. Menurut Ghozali (2011), Pengujian validitas dalam penelitian ini dilakukan dengan menggunakan Person Correlation yang terdapat dalam program SPSS 24.0 for Windows. Suatu pertanyaan dikatakan valid jika tingkat signifikasinya di bawah 0,05. Reliabilitas berkaitan dengan keterandalan suatu indikator. Informasi yang ada pada indikator ini tidak berubah-ubah, atau bisa disebut dengan kosisten. Uji reabilitas dilakukan untuk menguji apakah jawaban dari responden 
p-ISSN : 2599-1418

e-ISSN : 2599-1426

konsisiten. Suatu angket dikatakan reliabel jika jawaban seseorang terhadap pertanyaan adalah konsisten atau stabil dari waktu ke waktu. Pengujian realibilitas dalam penelitian ini dilakukan dengan menggunakan Alpha Cronbach yang terdapat dalam program SPSS 24.0 for Windows. Suatu instrumen dikatakan reliabel jika memiliki nilai Alpha Cronbach $>0,70$ (Ghozali, 2011).

Analisis data dilakukan untuk menguji hipotesis yang diajukan, yaitu untuk mengetahui ada tidaknya hubungan antara variabel bebas (X) dengan variabel terikat $(Y)$, sedangkan teknik analisis data yang digunakan dalam penelitian ini andalah regresi linier berganda. Menurut Sugiyono (2011), Regresi linier berganda digunakan untuk mengetahui pengaruh antara dua variabel bebas atau lebih terhadap variabel terikat. Sebelum dilakukan pengujian analisis regresi linear berganda, maka dilakukan pengujian prasyarat, yaitu uji asumsi klasik yang terdiri dari uji normalitas, uji heteroskedastisitas, dan uji multikolinearitas.

Uji normalitas digunakan untuk menguji apakah variabel terikat, variabel bebas atau keduanya mempunyai distribusi normal atau tidak. Model regresi dikatakan baik apabila memiliki distribusi normal atau mendekati normal. Menurut Ghozali (2011), Metode yang digunakan untuk melakukan pengujian ini adalah Statistic Kolgomorov-Smirnov. Kriteria yang digunakan adalah dengan membandingkan antar tingkat signifikansi yang didapat dengan tingkat signifikan (a), dikatakan berdistribusi normal apabila probabilitas $>\alpha$.

Uji heteroskedastisitas bertujuan untuk menguji apakah dalam sebuah model regresi terjadi ketidaksamaan varians dari residual $U j i$ dari satu pengamatan satu ke pengamatan yang lain (Ghozali, 2011). Jika varians dari residu atau dari satu pengamatan ke pengamatan yang lain tetap, maka disebut homokedastisitas, dan jika varians berbeda maka disebut heteroskedastisitas. Cara untuk mendeteksi heteroskedastisitas adalah
Jurnal Pendidikan Ekonomi Undiksha

Volume 10 No. 1 Tahun 2018

dengan melihat grafik scatterplot.

Menurut Ghozali (2011), Uji multikolonieritas bertujuan untuk menguji apakah pada model regresi ditemukan adanya korelasi antar variabel bebas. Model regresi yang baik seharusnya tidak terjadi korelasi diantara variabel bebas. Pengujian ada tidaknya gejala multikolonieritas dilakukan dengan memperhatikan nilai VIF (Variance Inflation Factor) dan Tolerance. Apabila nilai VIF berada di bawah 10 dan nilai Tolerance lebih hari 0,1 maka diambil kesimpulan bahwa model regresi tersebut tidak terdapat gejala problem multikolonieritas (Ghozali, 2011).

Teknik analisis data yang digunakan adalah analisis regresi linier berganda. Dari hasil analisis regresi linier berganda dapat diketahui persamaan garis regresi dengan menggunakan analisis koefisien beta sebagai berikut.

$Y=a+\beta_{1} X_{1}+\beta_{2} X_{2}+\varepsilon$

Keterangan:

$\mathrm{Y} \quad=$ Kesulitan belajar

$\alpha=$ Koefisien konstanta

$\beta_{1}, \beta_{2}=$ Koefisien regresi

$\mathrm{X}_{1} \quad=$ Lingkungan keluarga

$\mathrm{X}_{2}=$ Lingkungan sekolah

$\varepsilon=$ Error

Pengujian hipotesis secara parsial menggunakan uji t. Uji t dilakukan untuk melihat signifikansi pengaruh independen secara individu terhadap variabel dependen. Pengujian ini dilakukan dengan membandingkan $t_{\text {hitung }}$ dengan $t_{\text {tabel- }} \quad$ Adapun langkah-langkah pengujiannya, yaitu: (1) perumusan hipotesis; (2) menentukan tingkat signifikan (a) yaitu sebesar 5\%; (3) menentukan kriteria penerimaan atau penolakan $\mathrm{H}_{0}$ dengan melihat nilai signifikan. Jika signifikan $<5 \%$ maka $\mathrm{H}_{0}$ ditolak dan jika signifikan $>5 \%$ maka $\mathrm{H}_{0}$ diterima; dan (4) pengambilan keputusan.

Pengujian hipotesis secara simultan menggunakan uji F. Uji F dilakukan untuk melihat signifikansi pengaruh independen secara simultan terhadap variabel dependen. Pengujian ini dilakukan dengan membandingkan $F_{\text {hitung }}$ dengan 
p-ISSN : 2599-1418

e-ISSN : 2599-1426

$F_{\text {tabel- }} \quad$ Adapun langkah-langkah pengujiannya, yaitu: perumusan hipotesis, menentukan tingkat signifikan (a) yaitu sebesar 5\%, menentukan kriteria penerimaan atau penolakan $\mathrm{H}_{0}$ dengan melihat nilai signifikan. Jika signifikan $<5 \%$ maka $\mathrm{H}_{0}$ ditolak dan jika signifikan $>5 \%$ maka $\mathrm{H}_{0}$ diterima, dan pengambilan keputusan.

Analisis determinasi bertujuan untuk mengetahui atau menentukan seberapa besar pengaruh lingkungan keluarga dan lingkungan sekolah terhadap kesulitan belajar. Untuk menghitung koefisien determinasi $\left(R^{2}\right)$
Jurnal Pendidikan Ekonomi Undiksha

Volume 10 No. 1 Tahun 2018 menggunakan program SPSS 24.0 for Windows.

\section{HASIL DAN PEMBAHASAN \\ Hasil}

Hasil analisis data menunjukkan bahwa secara parsial pengaruh lingkungan keluarga terhadap kesulitan belajar pada siswa SMA Negeri 2 Singaraja dapat diketahui dengan menggunakan uji t. Perhitungan uji $t$ menggunakan bantuan program SPSS 24.0 for Windows dan pengujian hipotesis dilakukan pada taraf signifikansi 5\%. Hasil uji t dapat dilihat pada Tabel 1.

Tabel 2. Hasil Uji t untuk Pengaruh Lingkungan Sekolah Terhadap Kesulitan Belajar

\begin{tabular}{|c|c|c|c|c|c|c|}
\hline \multicolumn{2}{|r|}{ Model } & \multicolumn{2}{|c|}{$\begin{array}{c}\text { Unstandardized Coefficients } \\
\text { B Std Frror }\end{array}$} & $\begin{array}{c}\text { Standardized Coefficients } \\
\text { Beta }\end{array}$ & $\mathrm{t}$ & Sig. \\
\hline \multirow[t]{2}{*}{1} & (Co & 22,442 & 1,767 & & 12,700 & 0,000 \\
\hline & Lingkungan & 0,199 & 0,063 & 0,386 & 3,146 & 0,003 \\
\hline
\end{tabular}

a. Dependent Variable: Kesulitan belajar

Berdasarkan Tabel 2, diperoleh nilai $t_{\text {hitung }}=3,146$ dengan nilai $p$-value sebesar 0,000 . Nilai $t_{\text {hitung }}=3,146$ lebih besar dari $t_{\text {tabel }}=2,024$ dan $p$-value sebesar 0,003 lebih kecil dari $\alpha=0,05$, maka keputusannya $\mathrm{H}_{0}$ ditolak. Jadi, secara parsial terdapat pengaruh yang signifikan antara lingkungan sekolah terhadap kesulitan belajar pada siswa SMA Negeri 2 Singaraja.

Pengaruh lingkungan keluarga dan

lingkungan sekolah terhadap kesulitan belajar pada siswa SMA Negeri 2 Singaraja secara simultan diuji dengan menggunakan uji $F$. Perhitungan uji $F$ menggunakan bantuan program SPSS 24.0 for Windows dan pengujian hipotesis dilakukan pada taraf signifikansi $5 \%$. Hasil uji F dapat dilihat pada Tabel 3.

Tabel 3. Hasil Uji F Pengaruh Lingkungan Keluarga dan Lingkungan Sekolah Terhadap Kesulitan Belajar

\begin{tabular}{|c|c|c|c|c|c|c|}
\hline \multicolumn{7}{|c|}{ ANOVA } \\
\hline & Model & Sum of Squares & $d f$ & Mean Square & $\mathrm{F}$ & Sig. \\
\hline 1 & $\begin{array}{l}\text { Regression } \\
\text { Residual }\end{array}$ & $\begin{array}{l}64,553 \\
71,229\end{array}$ & $\begin{array}{c}2 \\
37\end{array}$ & $\begin{array}{c}32,276 \\
1,925\end{array}$ & 16,766 & 0,000 \\
\hline & Total & 135,781 & 39 & & & \\
\hline
\end{tabular}

a. Dependent Variable: Kesulitan belajar

b. Predictors: (Constant), Lingkungan sekolah, Lingkungan keluarga

Berdasarkan Tabel 2, diperoleh nilai $t_{\text {hitung }}=3,146$ dengan nilai $p$-value sebesar 0,000 . Nilai $t_{\text {hitung }}=3,146$ lebih besar dari $t_{\text {tabel }}=2,024$ dan $p$-value sebesar 0,003 lebih kecil dari $\alpha=0,05$, maka keputusannya $\mathrm{H}_{0}$ ditolak. Jadi, secara parsial terdapat pengaruh yang signifikan antara lingkungan sekolah terhadap kesulitan belajar pada siswa SMA Negeri 2 Singaraja.

Pengaruh lingkungan keluarga dan lingkungan sekolah terhadap kesulitan 
belajar pada siswa SMA Negeri 2 Singaraja secara simultan diuji dengan menggunakan uji F. Perhitungan uji $F$ menggunakan bantuan program SPSS 24.0 for Windows dan pengujian hipotesis dilakukan pada taraf signifikansi $5 \%$. Hasil uji $\mathrm{F}$ dapat dilihat pada Tabel 3.

Tabel 3. Hasil Uji F Pengaruh Lingkungan Keluarga dan Lingkungan Sekolah Terhadap Kesulitan Belajar

\begin{tabular}{ccccccc} 
& & \multicolumn{7}{c}{ ANOVA } & F & Sig. \\
\cline { 2 - 6 } & Model & Sum of Squares & $d f$ & Mean Square & 16,766 & 0,000 \\
\hline 1 & Regression & 64,553 & 2 & 32,276 & & \\
& Residual & 71,229 & 37 & 1,925 & & \\
\cline { 2 - 6 } & Total & 135,781 & 39 & & &
\end{tabular}

a. Dependent Variable: Kesulitan belajar

b. Predictors: (Constant), Lingkungan sekolah, Lingkungan keluarga

Berdasarkan Tabel 3, diperoleh nilai $F_{\text {hitung }}=16,766>F_{\text {tabel }}=3,260$ dengan nilai $p$-value sebesar 0,000 . Nilai $p$-value < 0,05 , sehingga secara simultan ada pengaruh yang signifikan antara lingkungan keluarga dan lingkungan sekolah terhadap kesulitan belajar.

Besar pengaruh lingkungan keluarga dan lingkungan sekolah terhadap kesulitan belajar pada siswa SMA Negeri 2 Singaraja dapat diketahui dari koefisien determinasi, yang ditunjukkan dengan nilai Adjusted R Square. Hasil analisis koefisien determinasi disajikan pada Tabel 4.

Tabel 4. Hasil Analisis Koefisien Determinasi

\begin{tabular}{ccccc}
\hline Model & $\mathrm{R}$ & $\mathrm{R}$ Square & Adjusted R Square & Std. Error of the Estimate \\
\hline 1 & 0,690 & 0,475 & 0,447 & 1,387479
\end{tabular}

a. Predictors:(Constant), Lingkungan sekolah, Lingkungan keluarga

Berdasarkan Tabel 4 ditunjukkan bahwa besar hasil perhitungan koefisien determinasi pada pengaruh lingkungan keluarga dan lingkungan sekolah terhadap kesulitan belajar pada siswa SMA Negeri 2 Singaraja secara simultan sebesar 0,447. Dengan demikian, besarnya sumbangan pengaruh untuk variabel lingkungan keluarga dan lingkungan sekolah terhadap kesulitan belajar secara simultan adalah sebesar $44,7 \%$, sedangkan sisanya sebesar
$55,3 \%$ dipengaruhi oleh faktor lain yang tidak termasuk dalam penelitian ini.

Berdasarkan hasil analisis regresi linier berganda, dapat diketahui persamaan garis regresi untuk mengetahui pengaruh lingkungan keluarga dan lingkungan sekolah terhadap kesulitan belajar pada siswa SMA Negeri 2 Singaraja dengan menggunakan analisis koefisien beta. Hasil perhitungan konstanta dan koefisien beta dapat dilihat pada Tabel 5 .

Tabel 5. Hasil Analisis Koefisien Beta

\begin{tabular}{|c|c|c|c|c|c|c|}
\hline \multirow{2}{*}{\multicolumn{2}{|c|}{ Model }} & \multicolumn{2}{|c|}{ Unstandardized Coefficients } & \multirow{2}{*}{$\begin{array}{c}\text { Standardized Coefficients } \\
\text { Beta }\end{array}$} & \multirow[b]{2}{*}{ t } & \multirow{2}{*}{ Sig. } \\
\hline & & B & Std. Error & & & \\
\hline \multirow[t]{3}{*}{1} & (Constant) & 22,442 & 1,767 & & 12,700 & 0,000 \\
\hline & $\begin{array}{l}\text { Lingkungan } \\
\text { keluarga }\end{array}$ & 0,171 & 0,043 & 0,485 & 3,951 & 0,000 \\
\hline & $\begin{array}{l}\text { Lingkungan } \\
\text { sekolah }\end{array}$ & 0,199 & 0,063 & 0,386 & 3,146 & 0,003 \\
\hline
\end{tabular}

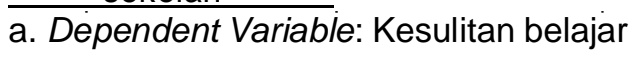


Berdasarkan perhitungan regresi linier berganda pada Tabel 5, maka didapat hasil persamaan regresi sebagai berikut.

$Y=a+\beta_{1} X_{1}+\beta_{2} X_{2}+\varepsilon$

$Y=22,442+0,171 X_{1}+0,199 X_{2}+\varepsilon$

Keterangan:

$\mathrm{Y}=$ kesulitan belajar

$\mathrm{X}_{1}=$ lingkungan keluarga

$\mathrm{X}_{2}=$ lingkungan sekolah

Berdasarkan model persamaan regresi yang terbentuk, dapat diinterpretasikan hasil bahwa konstanta sebesar 22,442 menunjukan jika variabel lingkungan keluarga $\left(\mathrm{X}_{1}\right)$ dan lingkungan sekolah $\left(X_{2}\right)$ bernilai konstan atau nol, maka variabel kesulitan belajar $(Y)$ memiliki nilai positif sebesar 22,442. Selanjutnya, variabel lingkungan keluarga $\left(X_{1}\right)$ memiliki koefisien positif sebesar 0,171 dan variabel lingkungan sekolah $\left(X_{2}\right)$ memiliki koefisien positif sebesar 0,199. Nilai koefisien regresi yang positif menunjukkan bahwa lingkungan keluarga $\left(X_{1}\right)$ dan lingkungan sekolah $\left(X_{2}\right)$ berpengaruh positif terhadap kesulitan belajar (Y). Hal ini menggambarkan bahwa peningkatan lingkungan keluarga $\left(X_{1}\right)$ dan lingkungan sekolah $\left(X_{2}\right)$ sebesar satu satuan akan dapat meningkatkan kesulitan belajar $(Y)$ sebesar nilai koefisien beta masingmasing variabel bebas dikalikan dengan besar kenaikan yang terjadi. Misalnya, setiap terjadi kenaikan lingkungan keluarga $\left(X_{1}\right)$ sebesar satu satuan, maka akan meningkatkan kesulitan belajar $(\mathrm{Y})$ sebesar 0,171 dan setiap terjadi kenaikan lingkungan sekolah $\left(\mathrm{X}_{2}\right)$ sebesar satu satuan, maka akan meningkatkan kesulitan belajar (Y) sebesar 0,199. Hal ini menunjukkan bahwa semakin tidak mendukung lingkungan keluarga dan lingkungan sekolah, maka semakin banyak kesulitan belajar siswa. Sebaliknya, semakin mendukung lingkungan keluarga dan lingkungan sekolah, maka semakin sedikit kesulitan belajar siswa.

\section{Pembahasan \\ Pengaruh Lingkungan Keluarga Terhadap Kesulitan Belajar \\ Hasil penelitian menunjukkan} bahwa terdapat pengaruh yang siginifikan antara lingkungan keluarga dengan kesulitan belajar. Persamaan regresi punya arah koefisien positif sebesar 0,171. Pengaruh positif menunjukkan bahwa hubungan lingkungan keluarga dan kesulitan belajar adalah searah. Jika lingkungan keluarga semakin tidak mendukung, maka kesulitan belajar siswa semakin banyak. Terdapat pengaruh yang signifikan lingkungan keluarga terhadap kesulitan belajar, yang ditunjukkan dengan nilai probabilitas uji $t$ untuk lingkungan keluarga adalah 0,000 lebih kecil dari 0,05 .

Berdasarkan hasil penelitian, dapat diambil suatu kesimpulan bahwa lingkungan keluarga berpengaruh signifikan terhadap kesulitan belajar. Hasil penelitian ini didukung teori yang dikemukan oleh Ahmadi dan Supriyono (2004), yang menjelaskan bahwa salah satu faktor penyebab kesulitan belajar adalah faktor lingkungan keluarga, meliputi orang tua, suasana rumah, dan keadaan ekonomi keluarga. Senada dengan itu, Dalyono (2009) menjelaskan salah faktor ekstern yang mempengaruhi kesulitan belajar siswa adalah lingkungan keluarga meliputi cara mendidik anak, hubungan orang tua dengan anak, suasana rumah tangga, dan keadaan ekonomi keluarga. Hasil penelitian ini didukung oleh hasil penelitian terdahulu yang dilakukan oleh Naja (2015), yang menunjukkan bahwa terdapat pengaruh yang signifikan antara lingkungan keluarga terhadap kesulitan belajar siswa. Penelitian lain yang mendukung hasil penelitian ini dilakukan oleh Marlina (2015), yang menyatakan bahwa terdapat pengaruh signifikan antara lingkungan keluarga terhadap Kesulitan Belajar.

\section{Pengaruh Lingkungan Sekolah Terhadap Kesulitan Belajar \\ Hasil penelitian menunjukkan bahwa terdapat pengaruh yang}


p-ISSN : 2599-1418

e-ISSN : 2599-1426

siginifikan antara lingkungan sekolah dengan kesulitan belajar. Persamaan regresi punya arah koefisien positif sebesar 0,199. Pengaruh positif menunjukkan bahwa hubungan lingkungan sekolah dan kesulitan belajar adalah searah. Jika lingkungan sekolah semakin tidak mendukung, maka kesulitan belajar siswa semakin banyak. Terdapat pengaruh yang signifikan lingkungan sekolah terhadap kesulitan belajar, yang ditunjukkan dengan nilai probabilitas uji $t$ untuk lingkungan sekolah adalah 0,003 lebih kecil dari 0,05 .

Berdasarkan hasil penelitian, dapat diambil suatu kesimpulan bahwa terdapat lingkungan sekolah berpengaruh signifikan terhadap kesulitan belajar. Hasil penelitian ini didukung teori yang dikemukan oleh Ahmadi dan Supriyono (2004), yang menjelaskan bahwa salah satu faktor penyebab kesulitan belajar adalah lingkungan sekolah, meliputi guru, sumber belajar, kondisi gedung, kurikulum, waktu sekolah, dan disiplin sekolah. Senada dengan itu, Syah (2008), menjelaskan bahwa salah faktor ekstern penyebab kesulitan belajar yang meliputi semua kondisi dan situasi lingkungan sekitar yang tidak mendukung aktivitas belajar siswa adalah lingkungan sekolah. Hasil penelitian ini didukung oleh hasil penelitian terdahulu yang dilakukan oleh Hidayah (2015), yang menunjukkan bahwa lingkungan sekolah berpengaruh signifikan terhadap kesulitan belajar. Penelitian lain yang mendukung hasil penelitian ini dilakukan oleh Nur (2016), yang menunjukkan bahwa lingkungan sekolah berpengaruh signifikan terhadap kesulitan belajar siswa.

\section{Pengaruh Lingkungan Keluarga dan Lingkungan Sekolah Terhadap Kesulitan Belajar \\ Hasil penelitian menunjukkan} bahwa secara simultan terdapat pengaruh yang signifikan antara lingkungan keluarga dan lingkungan sekolah terhadap kesulitan belajar, yang ditunjukkan dengan nilai probabilitas uji $\mathrm{F}$ sebesar 0,000 lebih kecil dari 0,05. Jika
Jurnal Pendidikan Ekonomi Undiksha

Volume 10 No. 1 Tahun 2018

lingkungan keluarga dan lingkungan sekolah semakin tidak mendukung, maka kesulitan belajar siswa semakin banyak.

Berdasarkan hasil penelitian, dapat diambil suatu kesimpulan bahwa secara simultan terdapat pengaruh yang signifikan antara lingkungan keluarga dan lingkungan sekolah terhadap kesulitan belajar. Hasil penelitian ini didukung teori yang dikemukan oleh Syah (2008), yang menjelaskan bahwa faktor ekstern penyebab kesulitan belajar yang meliputi semua kondisi dan situasi lingkungan sekitar yang tidak mendukung aktivitas belajar siswa adalah lingkungan keluarga dan lingkungan sekolah. Senada dengan itu, Dalyono (2009) menjelaskan faktor ekstern yang mempengaruhi kesulitan belajar siswa adalah lingkungan keluarga dan lingkungan sekolah. Hasil penelitian ini didukung oleh hasil penelitian terdahulu yang dilakukan oleh Adika (2010), dimana hasil analisis faktor menunjukkan bahwa faktor-faktor penyebab kesulitan belajar terdiri dari faktor ekstern, yaitu lingkungan keluarga dan lingkungan sekolah.

\section{SIMPULAN DAN SARAN Simpulan}

Berdasarkan hasil analisis data dan pembahasan hasil penelitian maka dapat ditarik simpulan sebagai berikut. Terdapat pengaruh lingkungan keluarga terhadap kesulitan belajar siswa SMA Negeri 2 Singaraja, Terdapat pengaruh lingkungan sekolah terhadap kesulitan belajar siswa SMA Negeri 2 Singaraja, Terdapat pengaruh lingkungan keluarga dan lingkungan sekolah terhadap kesulitan belajar siswa SMA Negeri 2 Singaraja.

\section{Saran}

Berdasarkan simpulan diatas, maka dapat dikemukakan beberapa saran sebagai berikut. (1) Bagi pihak pengelola SMA Negeri 2 Singaraja, agar lebih memperhatikan lingkungan sekolah agar lebih mendukung proses belajar siswa sebagai upaya untuk mengatasi kesulitan belajar, karena penelitian ini membuktikan bahwa lingkungan sekolah 
p-ISSN : 2599-1418

e-ISSN : 2599-1426

dapat mempengaruhi kesulitan belajar siswa. Selain itu, pihak sekolah berkoordinasi dengan orang tua siswa, agar memberikan dukungan penuh kepada siswa di rumah sehingga kesulitan belajar yang dialami siswa dapat diatasi. Hal ini disebabkan karena penelitian ini membuktikan bahwa lingkungan keluarga dapat mempengaruhi kesulitan belajar siswa; (2) Bagi peneliti selanjutnya yang tertarik untuk mengkaji aspek yang serupa mengenai pengaruh lingkungan keluarga dan lingkungan sekolah terhadap kesulitan belajar diharapkan untuk mengembangkan penelitian ini dengan menggunakan populasi dan sampel yang lebih luas, tidak hanya di SMA Negeri 2 Singaraja, tetapi juga di SMA lainnya agar hasil penelitian lebih teruji keandalannya; (3) Berdasarkan hasil perhitungan koefisien determinasi sebesar 0,475. Hal ini menunjukkan bahwa $47,5 \%$ variabel kesulitan belajar pada siswa SMA Negeri 2 Singaraja dipengaruhi oleh variabel lingkungan keluarga dan lingkungan sekolah, sedangkan $52,5 \%$ dipengaruhi oleh faktor lain yang tidak termasuk dalam penelitian ini. Dengan demikian disarankan bagi peneliti selanjutnya dapat menggunakan variabel lain yang mempengaruhi kesulitan belajar.

\section{DAFTAR PUSTAKA}

Abu, Ahmadi. 2008. Psikologi Belajar. Jakarta: Rineka Cipta.

Ahmadi, Abu dan Supriyono Widodo. 2004. Psikologi Belajar. Jakarta: PT Rineka Cipta.

Aqib, Zainal. 2002. Profesionalisme Guru dalam Pembelajaran. Jakarta: Insan Cendekia.

Dalyono. 2009. Psikkologi Pendidikan. Jakarta: Rineka Cipta.

Djamarah, Syaiful Bahri. 2006. Guru dan Anak Didik dalam Interaksi Edukatif. Jakarta: Rineka Cipta.

2011. Psikologi Belajar. Jakarta: PT. Rineka Cipta.

Ghozali, Imam. 2011. Aplikasi Analisis Multivariate dengan Program SPSS.
Jurnal Pendidikan Ekonomi Undiksha

Volume 10 No. 1 Tahun 2018

Semarang: Badan Penerbit Universitas Diponegoro.

Gunarsa, Singgih D. 2000. Psikologi Perkembangan Anak dan Remaja. Jakarta: PT Gunung Mulia.

Slameto. 2010. Belajar \& Faktor-Faktor yang Mempengaruhi. Jakarta: Rineka Cipta. 